UDC 541.13.544.65

\title{
ELECTROCHEMICAL DEPOSITION OF THIN SEMICONDUCTIVE Mo-S FILMS
}

\author{
V.A.Majidzade, S.F.Cafarova, A.Sh.Aliyev, N.B.Farhatova, D.B.Tagiyev \\ M.Naglyev Institute of Catalysis and Inorganic Chemistry, NAS of Azerbaijan \\ vuska_80@mail.ru
}

Received 17.12.2018

\begin{abstract}
The electrolytic co-deposition of thin Mo-S semiconductive films from aqueous electrolytes has been studied. The potential region for electrolytic co-deposition of molybdenum with sulphur was determined with the technical drawing of cyclic polarization curves by the potentiodynamic method on $\mathrm{Pt}$ and $\mathrm{Ni}$ supports. Samples of electrolytic co-deposition of molybdenum with sulphur were also obtained using a galvanostatic method on $\mathrm{Ni}$ supports. X-ray phase analysis of the obtained samples indicated to the formation of chemical compound of $\mathrm{MoS}_{2}$ composition.
\end{abstract}

Keywords: $\mathrm{MoS}_{2}$, polarization, thin films, electrodeposition, semiconductors.

In recent years, thin films of metal chalcogenides [1-4] have attracted much attention due to their unusual properties in functional materials and nanodevices. Thin films are widely used in the electronics, semiconductive engineering and optoelectronics. The utilization of such thin-film materials reduces the material capacity of devices appointed for various purposes.

Transition metal sulphides have been widely applied as solid lubricants, catalysts and cathode materials in lithium batteries. Amorphous chalcogenides are of more interest compounds.

Molybdenum disulphide $\left(\mathrm{MoS}_{2}\right)$ is one of the most promising, stable $n$-type semiconductor of layered structure [5-9]. In addition, due to the width of the band gap $(1.7 \mathrm{eV})$, it can be used as a part for solar cells [10] and photoelectrode materials for the production of hydrogen [11-13]. Recent studies have shown that $\mathrm{MoS}_{2}$ nanoparticles are promising and inexpensive alternatives to platinum using for electrochemical and photochemical hydrogen production from water [14-17].

There are various ways of synthesis of thin $\mathrm{MoS}_{2}$ films: chemical vapor deposition $[18,19]$, thermal evaporation [20, 21], hydrothermal synthesis [22], electrochemical method [23-25] etc.

In the world literature, there are a number of studies pertaining to the electrochemical deposition of thin semiconductor $\mathrm{MoS}_{2}$ films [23-28].
The authors of [23] electrochemically deposited $\mathrm{MoS}_{2}$ films from an aqueous electrolyte on a conductive glass, coated by tin oxide, and titanium substrates. X-ray diffraction studies show that films are naturally polycrystalline with a hexagonal structure. It was established that the film is an $n$-type semiconductor. The width of the band gap is $1.68 \mathrm{eV}$.

In [24], the electrodeposition of thin $\mathrm{MoS}_{2}$ films was studied at room temperature using ionic liquids as electrolyte. To find the optimum composition and deposition regime, the initial components Mo and $\mathrm{S}$ were added at different concentrations. Electrochemical deposition of $\mathrm{MoS}_{2}$ was confirmed by both Raman spectroscopy and X-ray photoelectron spectroscopy. The electrodeposited $\mathrm{MoS}_{2}$ films indicated characteristic fluorescent properties. These materials have optoelectronic properties for their application in photodetectors and lightemitting devices.

In work [25], molybdenum sulphide thin films were electrodeposited on glass carboniferous electrodes from aqueous electrolytes containing $10 \mathrm{mM}\left(\mathrm{NH}_{4}\right)_{2} \mathrm{MoS}_{4}$ and $0.2 \mathrm{M} \mathrm{KCl}$. Adhesion of the films was adequate only for electrodes pretreated with a potential cycle in 1.0 $\mathrm{M} \mathrm{HNO}_{3}$ and $0.1 \mathrm{M} \mathrm{NaF}$ to enhance the surface roughness. The deposited films that close to stoichiometry were obtained by annealing in Ar at $600^{\circ} \mathrm{C}$ for $60 \mathrm{~min}$.

The authors of the review article [26] showed that $\mathrm{MoS}_{2}$ films can be electrochemi- 
cally deposited in different media: from molten salts, ionic liquids, non-aqueous and aqueous solutions. The value of the potential at which $\mathrm{MoS}_{2}$ is deposited depends on the medium from which the deposition process occurs. Deposits obtained within more negative potentials were rich in molybdenum. It has been established that the temperature of the electrolyte significantly influences the growth of deposits, since a higher temperature leads to faster growth rates of the crystals, as well as to adhesion of the films. At high $\mathrm{pH}$ values, the deposition rate is relatively low, while at lower $\mathrm{pH}$ values, the mixed phase films of $\mathrm{MoS}_{2}$ are obtained. It was found that the electrodeposition of $\mathrm{MoS}_{2}$ from high-temperature molten salts makes possible to obtain well-defined crystals. The photoelectrochemical behavior of $\mathrm{MoS}_{2}$ photoanodes in neutral and alkaline electrolytes has shown that the $\mathrm{MoS}_{2}$ semiconductor is oxidized, which leads to its decomposition into metal ions and molecular sulphur.

Nanostructured thin films of molybdenum disulphide were deposited on various substrates in an electrolyzer at a constant current, from an aqueous electrolyte containing ions of molybdate and sulphide [27]. Annealing of deposited thin films at higher temperatures in the range of $450-700^{\circ} \mathrm{C}$ transforms the deposited amorphous films into a nanocrystalline structure. UV and visible spectra confirmed the presence of Mo-S $\mathrm{S}_{x}$ in the deposited films.

In $[28,29]$ authors produced thin films of molybdenum sulphide $\left(\mathrm{MoS}_{x}\right)$ on indium-tin oxide polyethylene naphthalate (ITO/PEN) substrates by pulsed electrochemical deposition way. The results showed that the thin $\operatorname{MoS}_{x}$ films are uniformly deposited onto the flexible ITO/PEN substrates and they are active catalysts for the reduction of the triiodide. $\mathrm{MoS}_{x}$ thin films are produced in a simple and rapid manner at room temperature and atmospheric pressure. This is an important practical contribution to the production of flexible low-cost thin-film solar cells based on plastic substrates.

Analysis of literature leads to the conclusion that there is no optimum variant for obtaining thin semiconductor $\mathrm{MoS}_{2}$ films. This de- pends on the type and properties of the desired film, on the choice of substrate etc.

Therefore, the aim of our work is to study the kinetics and mechanism of the process of electrodeposition of molybdenum with sulphur from an aqueous solution, the determination of the potential region in which the $\mathrm{MoS}_{2}$ compound is deposited. As known, to obtain thin films of semiconductor materials by co-deposition, the first action is to study the kinetics and mechanism of the electroreduction process of the components separately. The latter was investigated by us beforehand in works $[30,31]$.

\section{Experimental part}

The process of electrochemical deposition of molybdenum with sulphur from aqueous electrolytes was carried out as follows. Solutions containing molybdenum and sulphur are prepared separately. The solution of molybdenum is $1 \mathrm{M} \mathrm{Na}_{2} \mathrm{MoO}_{4} \cdot 2 \mathrm{H}_{2} \mathrm{O}$, and of sulphur is $0.1 \mathrm{M} \mathrm{Na}_{2} \mathrm{SO}_{3}$.

Polarization curves were drawn with the IVIUMSTAT Electrochemical Interface potentiostat. At the same time an electrochemical three-electrode glass cell was used. The Pt electrode with an area of $0.4 \mathrm{~cm}^{2}$ and a Ni electrode with an area of $2 \mathrm{~cm}^{2}$ were used as working electrodes. The reference electrode was a silver chloride electrode, and an auxiliary electrode was a platinum plate with an area of $4 \mathrm{~cm}^{2}$. To regulate the temperature in the cell, a universal ultratermostat UTU-4 was applied.

The phase composition of the obtained thin layers was studied using X-ray diffraction analysis of D2 Phazer of Bruker Company $\left(\mathrm{Cu} K_{\alpha}, \mathrm{Ni}\right.$-filter).

Morphology, relief and elemental composition of the samples were analyzed using a Scanning Electron Microscope (SEM) "Carel Zeiss Siqma" equipped with an EDAX unit.

At the beginning of the experiments, the $\mathrm{Pt}$ and $\mathrm{Ni}$ electrodes were purified in concentrated nitric acid, and then washed with distilled water. Then, the Ni-electrodes were electrochemically polished in a mixed solution of sulphuric, phosphoric and citric acids under certain conditions $\left(T=293-303 \mathrm{~K}, i=5 \cdot 10^{-1} \mathrm{~A} / \mathrm{dm}^{2}\right.$, $\tau=180 \mathrm{~s}$ ) and washed with distilled water. 


\section{Results and discussion}

As indicated above, with the study of the electrochemical reduction of molybdenum [30] and sulphur [31], the potentials regions for the deposited components is separately determined.

The results of the experiments showed that the electrochemical reduction of molybdate ions occurs in the range of potentials $0.2-(-0.7) \mathrm{V}$ and the ion sulphite within $0.4-(-0.3) \mathrm{V}$, respectively, according to the reactions (1), (2):

$$
\begin{aligned}
& \mathrm{Mo}(\mathrm{VI}) \rightarrow \mathrm{Mo}(\mathrm{III}) \rightarrow \mathrm{Mo}^{0}, \\
& \mathrm{~S}(\mathrm{IV}) \rightarrow \mathrm{S}^{0} \rightarrow \mathrm{S}^{2-} \text {. }
\end{aligned}
$$

Taking into account the potentials of electrochemical reduction of molybdate and sulphite ions, cyclic polarization curves with a stationary potential of $-0.7 \mathrm{~V}$ were drawn in $1 \mathrm{M} \mathrm{Na}_{2} \mathrm{MoO}_{4} \cdot 2 \mathrm{H}_{2} \mathrm{O}+0.1 \mathrm{M} \mathrm{Na}_{2} \mathrm{SO}_{3}$ electrolyte (Figure 1).

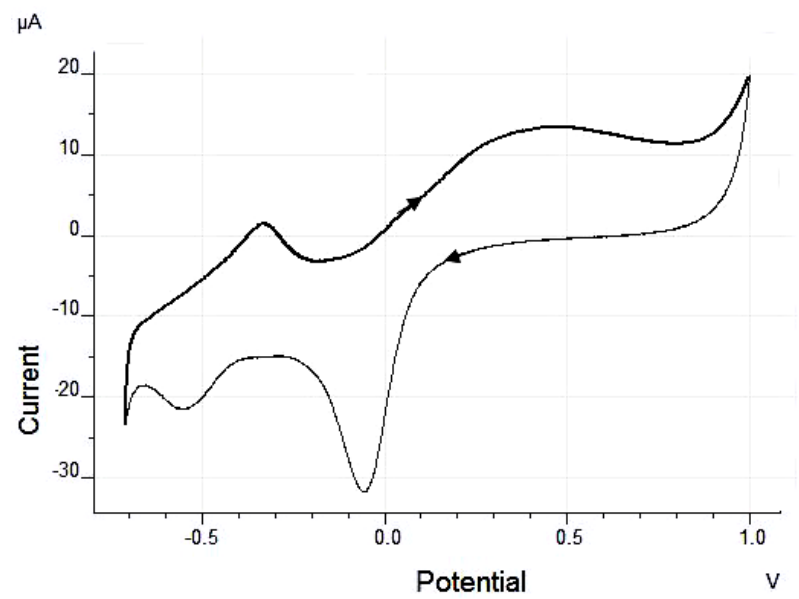

Fig. 1. The cyclic polarization curve of electrolytic codeposition of molybdenum with sulfur from aqueous electrolytes on the Pt electrode; $T=338 \mathrm{~K}, E_{\mathrm{V}}=0.03 \mathrm{~V} / \mathrm{s}$.

Figure 1 shows the cyclic polarization curve of the electrochemical co-deposition of molybdenum with sulphur. As can be seen, the electrochemical deposition occurs in steps within the potential range of $0.5-(-0.70) \mathrm{V}$ on the $\mathrm{Pt}$ electrode due to following reaction:

$$
\begin{aligned}
& \mathrm{S}(\mathrm{IV}) \stackrel{I}{\rightarrow} \mathrm{S}^{0} \stackrel{I I}{\rightarrow} \mathrm{S}^{2-}, \\
& \mathrm{Mo}^{6+}+2 \mathrm{~S}^{2-}+2 \mathrm{e}^{-} \rightarrow \mathrm{MoS}_{2} .
\end{aligned}
$$

On the surface of the electrode, the electrodeposition of sulphur occurs up to $-0.3 \mathrm{~V}$ (reaction 3) starting from 0.3V (Figure 2).

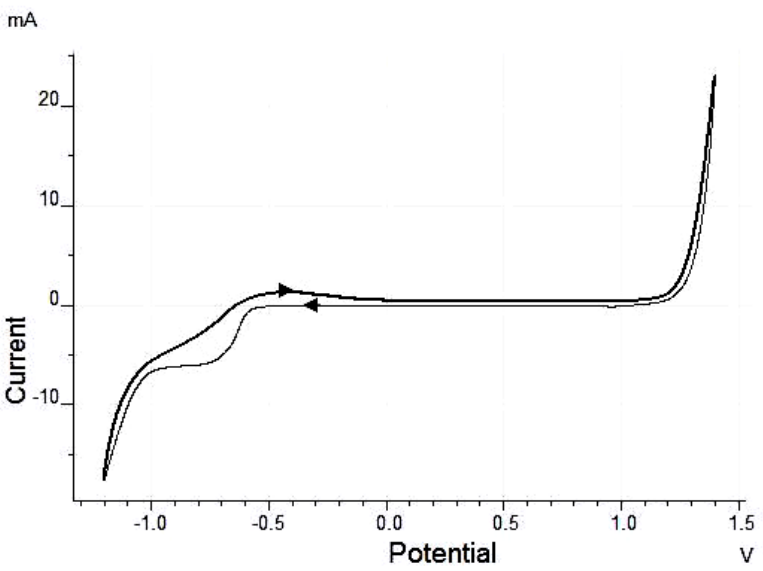

Fig. 2. Cyclic polarization curve of electrolytic co-deposition of molybdenum with sulphur from aqueous electrolytes on a Ni-electrode; electrolyte: $1 \mathrm{M} \mathrm{Na}_{2} \mathrm{MoO}_{4} \cdot 2 \mathrm{H}_{2} \mathrm{O}+0.1 \mathrm{M}$ $\mathrm{Na}_{2} \mathrm{SO}_{3}, T=338 \mathrm{~K}, E_{\mathrm{V}}=0.03 \mathrm{~V} / \mathrm{s}$.

After that, from $-0.4 \mathrm{~V}$ potential begins a deep recovery of $S$ before $S^{2-}$ and at the same time occurs electrodeposition molybdenum with sulphur to $-0.7 \mathrm{~V}$ (reaction 3 , II and reaction 4). Alongside with this the surface of electrode is covered by a black lager. The continuation of the process was represented on the anode branch of the cyclic curve. The peak obtained at potential of $-0.3 \mathrm{~V}$ refers to the dissolution of the obtained molybdenum compound with sulphur, whereas after 0.2 to $1.0 \mathrm{~V}$ - to the dissolution of sulphur. The study of the process of electrodeposition to $-0.7 \mathrm{~V}$ is due to the fact that after this potential, hydrogen evolution is observed which degrades the quality of the obtained Mo-S films.

The electrolytic co-deposition of molybdenum with sulphur was also investigated on a $\mathrm{Ni}$ - electrode. As can be seen from Figure 2, in comparison with the Pt electrode, the electrodeposition on the Ni-electrode occurs at more cathodic potential - within the range of $-0.55-$ $(-1.3) \mathrm{V}$.

After finding the potential for electrolytic co-deposition of molybdenum with sulphur, further studies have been devoted to the selection of the optimum electrolyte composition and to the electrolysis regime for obtaining the stoichiometric composition of the $\mathrm{MoS}_{2}$ compound. For this, the influence of certain factors on the process of electrolytic co-deposition has been studied. 


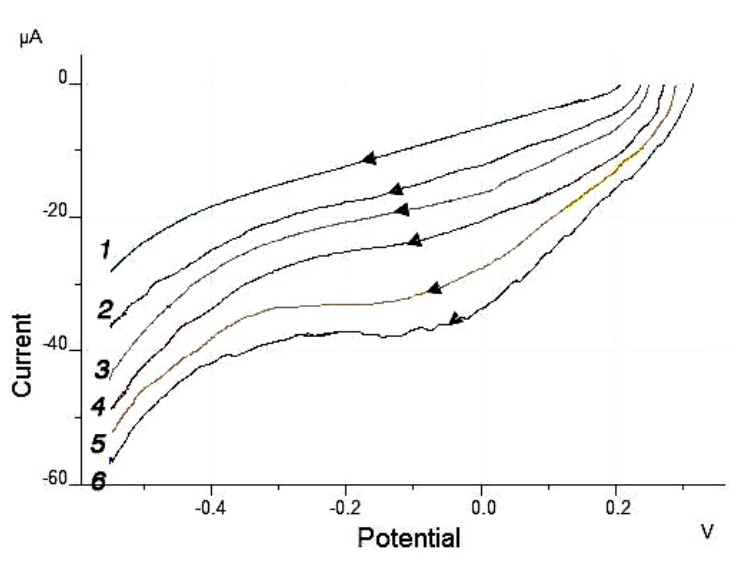

Fig. 3. The effect of the concentration of molybdate ions on the electrolytic co-deposition of molybdenum with sulfur from aqueous electrolytes on the Pt electrode. Electrolyte $-\mathrm{Na}_{2} \mathrm{MoO}_{4} \cdot 2 \mathrm{H}_{2} \mathrm{O}, \mathrm{M}$ : $1-0.1,2-0.2,3-0.4,4-0.8,5-1.0,6-1.2+$ $0.1 \mathrm{Na}_{2} \mathrm{SO}_{3} . T=338 \mathrm{~K}, E_{\mathrm{V}}=0.03 \mathrm{~V} / \mathrm{s}$.

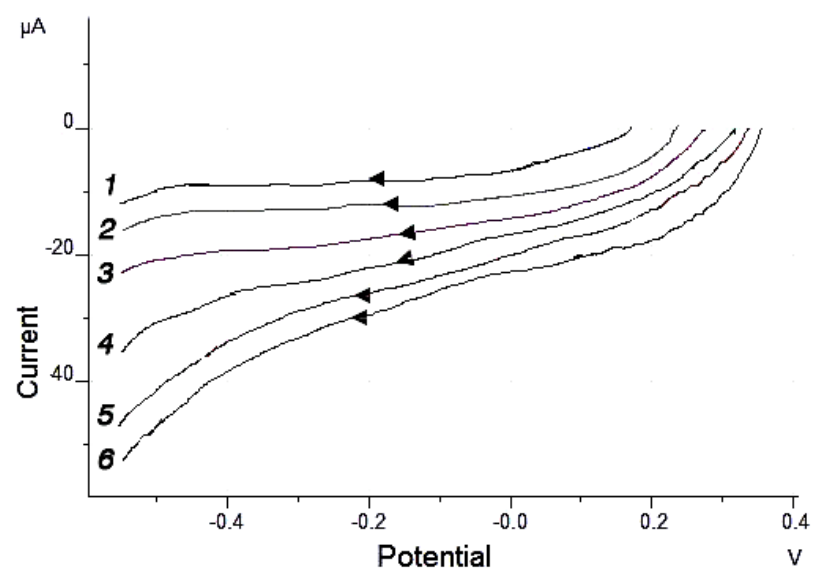

Fig. 4. The effect of the concentration of sulfite ions on the electrolytic co-deposition of molybdenum with sulfur from aqueous electrolytes on the Pt electrode. Electrolyte $-\mathrm{Na}_{2} \mathrm{SO}_{3}, \mathrm{M}: 1-0.01,2-0.02,3-0.04,4-$ $0.08,5-0.1,6-0.2+1.0 \mathrm{Na}_{2} \mathrm{MoO}_{4} \cdot 2 \mathrm{H}_{2} \mathrm{O} ; T=338 \mathrm{~K}$, $E_{\mathrm{V}}=0.03 \mathrm{~V} / \mathrm{s}$.
First, the effect of the concentration of the initial components on the electrolytic codeposition of thin Mo-S films was investigated. This process has been studied in two steps: the effect of the concentration of molybdate and sulphite ions separately (Figure 3).

Figure 3 shows the effect of the concentration of molybdate ions (0.1-1.2) $\mathrm{M}$ on the codeposition of molybdenum with sulphur. With increasing the concentration of molybdate ions, the potential value of electrolytic co-deposition shipts to the positive side. The increase in concentration also affects the composition and quality of the obtained Mo-S thin films. Table 1 shows the results of the experiments. As can be seen from the table, black, smooth, crystalline, uniform coatings of stoichiometric composition are obtained at $1.0 \mathrm{M}$ of Mo concentration. After this, the quality of the films deteriorates and the amount of molybdenum in the composition increases. Therefore, the optimum concentration of molybdenum was chosen (1.0-1.1)M.

In Figure 4, the effect of the concentration of the sulphite ions on the electrolytic codeposition of molybdenum with sulphur is shown. The study was carried out within the (0.01-0.2)M interval.

According to Figure 4, with increasing the concentration of sulphite ions, the potential of electrolytic co-deposition shifts to the positive side (from 0.15 to $0.35 \mathrm{~V}$ ).

An increase in the concentration of sulphite ions in the electrolyte significantly affects the composition and quality of the obtained thin Mo-S films.

Table 2 shows the results of the experiments. As can be seen, black, smooth, crystalline, uniform Mo-S coatings of stoichiometric composition are obtained at $0.1 \mathrm{M}$ concentration of sulphite ions.

Table 1. The effect of molybdate ions concentration on the composition and quality of electrodeposited thin Mo-S films

\begin{tabular}{|c|c|c|l|}
\hline \multicolumn{2}{|c|}{ Composition of electrolyte, $\mathrm{M}$} & $\begin{array}{c}\text { Amount of Mo in the } \\
\text { film, } \%\end{array}$ & \multicolumn{1}{|c|}{ Appearance of the coatings } \\
\cline { 1 - 2 } $\mathrm{Na}_{2} \mathrm{MoO}_{4} \cdot 2 \mathrm{H}_{2} \mathrm{O}$ & $\mathrm{Na}_{2} \mathrm{SO}_{3}$ & 21.6 & black, uneven, amorphous, loose \\
\hline 0.1 & 0.1 & 33.2 & black, uneven, semicrystalline, loose \\
\hline 0.2 & 0.1 & 42.8 & black, amorphous, uniform, smooth \\
\hline 0.4 & 0.1 & 54.3 & black, uniform, amorphous, smooth \\
\hline 0.8 & 0.1 & 60.1 & black, smooth, crystalline, uniform \\
\hline 1.0 & 0.1 & 65.3 & black, crystalline, uneven, loose \\
\hline 1.2 & 0.1 & & \\
\hline
\end{tabular}


Table 2. The influence of the concentration of sulphite ions on the composition and quality of electrodeposited thin Mo-S films

\begin{tabular}{|c|c|c|c|}
\hline \multicolumn{2}{|c|}{ Composition of electrolyte, $\mathrm{M}$} & $\begin{array}{c}\text { Amount of } \mathrm{S} \text { in the } \\
\text { film, } \%\end{array}$ & Appearance of coatings \\
\hline $\mathrm{Na}_{2} \mathrm{SO}_{3}$ & $\mathrm{Na}_{2} \mathrm{MoO}_{4} \cdot 2 \mathrm{H}_{2} \mathrm{O}$ & 11.7 & black, uniform, amorphous, loose \\
\hline 0.01 & 1 & 19.2 & black, uniform, amorphous, smooth \\
\hline 0.02 & 1 & 26.4 & black, amorphous, uniform, smooth \\
\hline 0.04 & 1 & 32.1 & black, uneven, semicrystalline, loose \\
\hline 0.08 & 1 & 39.9 & black, smooth, semicrystalline, loose, uniform \\
\hline 0.1 & 1 & 59.3 & black, semicrystalline, uneven, loose \\
\hline 0.2 & 1 & &
\end{tabular}

In addition, from Figure 4 it follows that with an increase in the concentration of sulphite ions, the rate of the electrochemical reaction decreases. This is due to the fact that at high cathode potentials with an increase in the concentration of sulphite ions, on the electrode surface, first sulphur deposits which cover the electrode surface and makes it difficult for current to flow. Therefore, Mo-S electrodeposition occurs in small cathode currents. As soon as, at shift the cathode potential begins reduction sulphur to sulphide ions, the rate of the electrochemical reaction is accelerated, and thin films Mo-S there are deposited.

After studying the influence of the concentration of the initial components, the effect of temperature on the process of electrolytic codeposition of thin Mo-S semiconductor films was also studied by the potentiodynamic method within the 298-348 K intervals.

With increasing of the electrolyte temperature, the potential of electrolytic codeposition of Mo-S shifts to more positive direction. In addition, the temperature also affects the quality of the deposited thin films and their adhesion to the surface of the electrode. There-

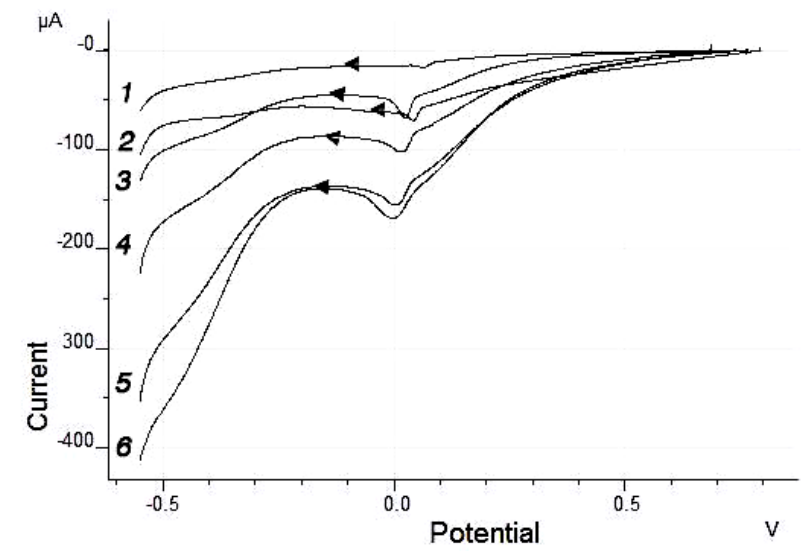

fore, to obtain black, smooth, crystalline, uniform Mo-S coatings with the stoichiometric composition, an optimum temperature interval 333-338 K was chosen.

The effect of the scanrate was studied at an interval of $0.005-0.2 \mathrm{~V} / \mathrm{s}$.

With increasing the scanrate, the potential of electrolytic co-deposition of molybdenum with sulphur shifts to the positive side and the cathode current increases (Fiure 5). When investigating the effect of the scanrate, black, smooth, crystalline, uniform Mo-S coatings with stoichiometric composition are obtained at $0.03-0.06 \mathrm{~V} / \mathrm{s}$.

Figure 6 shows the morphology, topography and of elements composition of Mo-S samples obtained by electrolytic co-deposition using a scanning electron microscope.

The results of a scanning electron microscope show that electrodeposition of both components is carried out on the Pt and Ni electrodes. And the X-ray phase analysis shown in Figure 7 proves the preparation of the chemical compound $\mathrm{MoS}_{2}$, which was deposited by the potentiostatic method on the Ni electrode.

Fig. 5. The effect of scanrate on the electrolytic co-deposition of molybdenum with sulfur from the aqueous electrolytes on the $\mathrm{Pt}$ electrode. $T=338$ K. Electrolyte: $1 \mathrm{M} \mathrm{Na} \mathrm{Na}_{2} \mathrm{MoO}_{4} \cdot 2 \mathrm{H}_{2} \mathrm{O}+$ $0.1 \mathrm{M} \mathrm{Na}_{2} \mathrm{SO}_{3}, E_{\mathrm{V}}$ (V/s.): $1-0.005,2-0.01,3-$ $0.03,4-0.06,5-0.12,6-0.2$. 

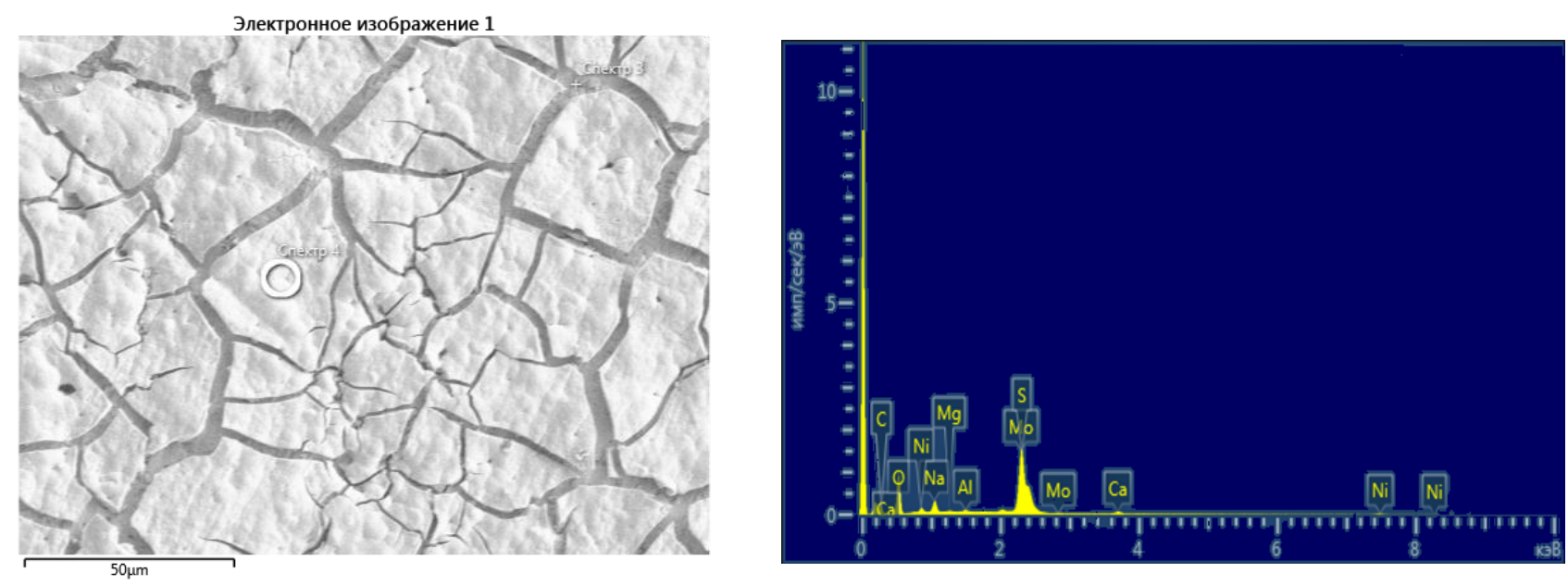

Fig. 6. SEM and EDX analyses of electrodeposited thin films of Mo-S. Electrolyte $-1 \mathrm{M} \mathrm{Na}_{2} \mathrm{MoO}_{4} \cdot 2 \mathrm{H}_{2} \mathrm{O}+$ $0.1 \mathrm{M} \mathrm{Na}_{2} \mathrm{SO}_{3} ; T=338 \mathrm{~K}, E_{\mathrm{V}}=0.03 \mathrm{~V} / \mathrm{s}$.

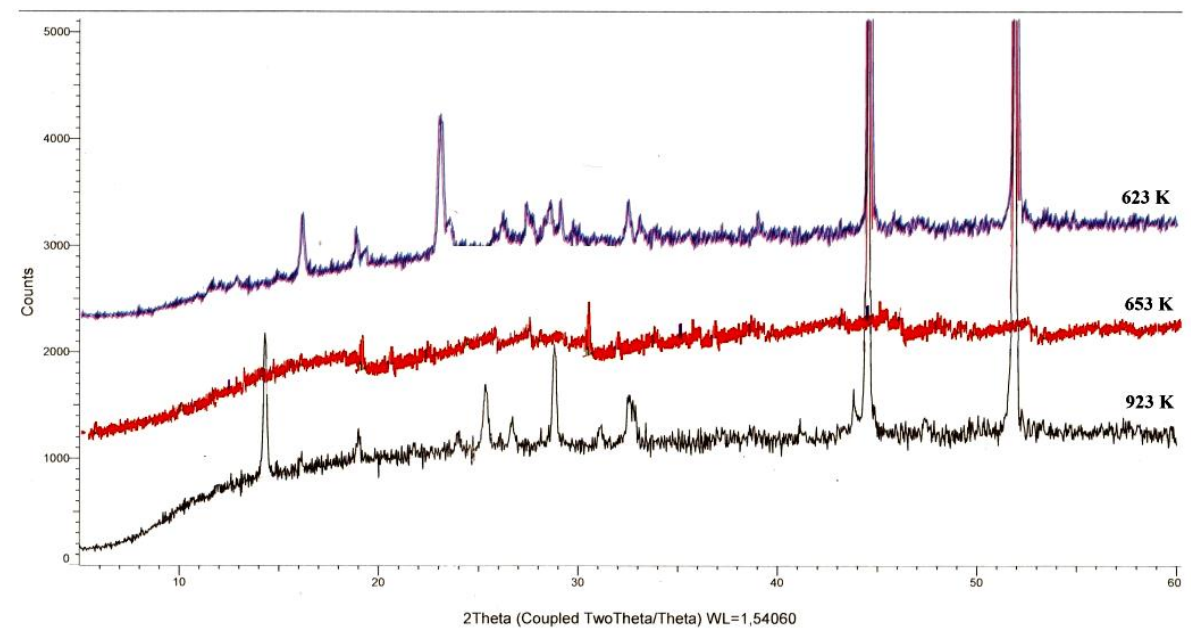

Fig. 7. X-ray phase analysis of electrodeposited Mo-S thin films. Electrolyte: $1 \mathrm{M} \mathrm{Na}_{2} \mathrm{MoO}_{4} \cdot 2 \mathrm{H}_{2} \mathrm{O}+0.1 \mathrm{M}$ $\mathrm{Na}_{2} \mathrm{SO}_{3} . T=338 \mathrm{~K}, E_{\mathrm{V}}=0-03 \mathrm{~V} / \mathrm{s}$.

Figure 7 shows 3 radiographs of the compounds obtained. Despite the fact that the samples were deposited in the same optimum mode, depending on the heat treatment temperature in an argon atmosphere, when heated to $623 \mathrm{~K}$, there is formed compound $\mathrm{MoS}_{2}$, by heating to the $653 \mathrm{~K}$ the compound $\mathrm{Mo}_{3} \mathrm{~S}_{4}$ and by heating to $923 \mathrm{~K}$ the compound $\mathrm{NiMoO}_{4}$.

\section{Conclusions}

The electrodeposition process of Mo-S on Pt and Ni electrodes from aqueous electrolytes was studied by cyclic voltamperometry. It was determined that the electrolytic codeposition on the Pt electrode occurs within the potential range of $-0.5-(-0.70) \mathrm{V}$, and on the Ni electrodes within $0.55-(-1.3) \mathrm{V}$. The influence of various factors (concentration of components, temperature, and potential sweep) on the electrolytic co-deposition of molybdenum with sulphur has been also studied. The results of the experiments show that black, smooth, crystalline, uniform coatings are obtained at $1.0 \mathrm{M}$ concentration of the molybdate ions, $0.1 \mathrm{M}$ concentration of the sulphite ions, at $0.03 \mathrm{~V} / \mathrm{s}$ scanrate, at $338 \mathrm{~K}$ temperature and 7 $\mathrm{mA} / \mathrm{cm}^{2}$ current density.

\section{Reference}

1. Huseynov G.M., Mammadova N.A., Imanov H.A. Obtaining of nanosized compound $\mathrm{Sb}_{2} \mathrm{~S}_{3}$ on 
the basis of tioacetamide and antimony(III) chloride // Chemical Problems. 2017. № 3. P. 329334.

2. Aliyev A.Sh., Eminov Sh.O., Sultanova T.Sh. et al. Electrochemical production of thin films of cadmium sulphide on nickel electrodes and research into their morphology // Chemical Problems. 2016. № 2. P. 139-145.

3. Aliyev A.Sh., Majidzade V.A., Soltanova N.Sh., Tagiyev D.B., Fateev V.N. Some features of electrochemically deposited CdS nanowires // Chemical Problems. 2018. V. 16. № 2. P. 178 185.

4. Majidzade V.A. Effect of various factors on the composition of electrolytic thin films $\mathrm{Sb}-\mathrm{Se} / /$ Chemical Problems. 2018. V.16. № 3. P. 331-336.

5. Radisavljevic B., Radenovic A., Brivio J., Giacometti V., Kis A. Single-layer $\mathrm{MoS}_{2}$ transistors. // Nat. Nanotechnol. 2011. V. 6. P. 147-150.

6. Radisavljevic B., Whitwick M.B., Kis A. Integrated circuits and logic operations based on single-layer $\mathrm{MoS}_{2}$. // ACS Nano 2011. V. 5. No12. P. 9934-9938.

7. Wang Q.H., Kalantar-Zadeh K., Kis A., Coleman J.N. Strano M.S. Electronics and optoelectronics of two-dimensional transition metal dichalcogenides // Nat. Nanotechnol. 2012. 7. P. 699-712.

8. Jason S.Ross, Philip Klement, Aaron M. Jones, Nirmal J. Ghimire, Jiaqiang Yan, D. G. Mandrus, Takashi Taniguchi, Kenji Watanabe, Kenji Kitamura, Wang Yao, David H. Cobden, Xiaodong $\mathrm{Xu}$. Electrically tunable excitonic light-emitting diodes based on monolayer $\mathrm{WSe}_{2} p-n$ junctions // Nat. Nanotechnol. 2014. 9. P. 268-272.

9. Majidzade V.A., Cafarova S.F., Aliyev A.Sh., Tagiyev D.B. Influence of various factors on the composition of electrodeposited thin films Mo-S // Azerb. Chem. Journ. 2018. № 3. P. 6-10.

10. Lauritsen J.V., Kibsgaard J., Helveg S., Henrik Topsøe, Bjerne S. Clausen, Erik Lægsgaard Flemming Besenbacher. Size-dependent structure of $\mathrm{MoS}_{2}$ nanocrystals // Nature Nanotechnology. 2007. V. 2 No 1. P. 53-58.

11. Jaramillo T.F., Jwrgensen K.P., Bonde J., Nielsen J.H., Horch S., Chorkendorff I. Identification of active edge sites for electrochemical $\mathrm{H}_{2}$ evolution from $\mathrm{MoS}_{2}$ nanocatalysts // Science. 2007. V. 317. 5834. P. 100-102.

12. Zong X., Yan H., Wu G. et al., Enhancement of photocatalytic $\mathrm{H}_{2}$ evolution on $\mathrm{CdS}$ by loading $\mathrm{MoS}_{2}$ as cocatalyst under visible light irradiation //J. Am. Chem. Soc. 2008. V. 130. P. 7176-7177.

13. B. Hinnemann, P. G.Moses, J. Bonde, Kristina P. Jørgensen, Jane H. Nielsen, Sebastian Horch, Ib Chorkendorff, Jens K. Nørskov. Biomimetic hydrogen evolution: $\mathrm{MoS}_{2}$ nanoparticles as catalyst for hydrogen evolution // J. Am. Chem. Soc. 2005.V. 127. P. 5308-5309.
14. Hinnemann B., Nwrskov J.K., Topsøe H. A Density Functional Study of the chemical differences between Type I and Type II $\mathrm{MoS}_{2}$ - based structures in hydrotreating catalysts // J. Phys. Chem. B. 2005. V. 109. No 6. P. 2245-2253.

15. Li Y., Wang H., Xie L., Liang Y., Hong G., Dai H. $\mathrm{MoS}_{2}$ nanoparticles grown on graphene: an advanced catalyst for the hydrogen evolution reaction // J. Am. Chem. Soc. 2011. V. 133 No 19. P. 7296-7299.

16. Aliyev A.Sh., Guseynova R.G., Gurbanova U.M., Babanly D.M., Fateev V.N., Pushkareva I.V., Tagiyev D.B. Electrocatalysts for water electrolysis // Chemical. Problems. 2018. V. 16. № 3. P. 283-306.

17. Kulova T.L., Nikolaev I.I., Fateev V.N., Aliyev A.Sh. Electrochemical systems of energy accumulation. Chemical Problems. 2018. V. 16. № 1. P. 9-34.

18. Hadallia Bergeron, Vinod K. Sangwan, Julian J. McMorrow, Gavin P. Campbell, Itamar Balla, Xiaolong Liu, Michael J. Bedzyk, Tobin J. Marks, Mark C. Hersam. Chemical vapor deposition of monolayer $\mathrm{MoS}_{2}$ directly on ultrathin $\mathrm{Al}_{2} \mathrm{O}_{3}$ for low-power electronics // Appl. Phys. Lett. 2017. V. 110. No 5. P. 053101-5.

19. Jihun Mun, Dongbin Kim, Juyoung Yun, Yonghyeon Shin, Sangwoo Kang, Taesung Kim. Chemical Vapor Deposition of $\mathrm{MoS}_{2}$ Films // ECS Trans. 2013. V. 58. No 7. P. 199-202.

20. Sivarajan S., Padmanabhan R. Characterization of thermally evaporated $\mathrm{MoS}_{2}$ thin film coatings // Material stoday: proceedings. 2016. V. 3. No 6. 2016. P. 2532-2536.

21. Xiying Ma, Miaoyuan Shi. Thermal Evaporation Deposition of Few-layer $\mathrm{MoS}_{2}$ Films // NanoMicro Letts. 2013. V. 5. No 2. P. 135-139.

22. Mohammad Al-Mamun, Haimin Zhang, Porun Liu, Yun Wang, Jun Cao, Huijun Zhao. Directly hydrothermal growth of ultrathin $\mathrm{MoS}_{2}$ nanostructured films as high performance counter electrodes for dye-sensitised solar cells // RSC Advances, 2014. 41. P. 21277-21283.

23. Anand T.S. Synthesis and Characterization of $\mathrm{MoS}_{2}$ Films for Photoelectrochemical Cells // Sains Malaysiana. 2009. V. 38. No 1. P. 85-89.

24. Sankaran Murugesan, Arunkumar Akkineni, Brendan P. Chou, Micah S. Glaz, David A. Vanden Bout, Keith J. Stevenson. Room Temperature Electrodeposition of Molybdenum Sulphide for Catalytic and Photoluminescence Applications // ACS Nano, 2013. V. 7. No 9. P. 8199-8205.

25. Bamidele D. Falola, Tomasz Wiltowski, Ian I. Suni. Electrodeposition of $\mathrm{MoS}_{2}$ for Charge Storage in Electrochemical Supercapacitors // J. Electrochem. Soc. 2016. V.163. No 9. P. D568-D574.

26. Akif Shikhan Aliyev, Mahmoud Elrouby, Samira Fikret Cafarova. Electrochemical synthesis of 
molybdenum sulphide semiconductor // Materials Science in Semiconductor Processing. 2015. V. 32. P. 31-39.

27. Ghosh S. K., Srivastava C., Nath S., Celis J. P. Simple Formation of Nanostructured Molybdenum Disulphide Thin Films by Electrodeposition // Int. J. Electrochem. 2013. Article ID 138419. 7 p. http: //dx.doi.org/10.1155/2013/138419.

28. Chao-Kuang Cheng, Chien-Kuo Hsieh. Electrochemical deposition of molybdenum sulphide thin films on conductive plastic substrates as platinum-free flexible counter electrodes for dyesensitized solar cells // Thin Solid Films. 2015. V. 584. P. 52-60.

29. Che-Hsien Lin, Chuen-Horng Tsai, Fan-Gang Tseng, Chen-Chi M. Ma, Hsuan-Chung Wu, ChienKuo Hsieh. Three-dimensional vertically aligned hybrid nanoarchitecture of two-dimensional molybdenum disulphide nanosheets anchored on directly grown one-dimensional carbon nanotubes for use as a counter electrode in dye-sensitized solar cells // J. Alloys and Compounds. 2017. V. 692. P. 941-949. https: // +doi.org/10.1016/j. jallcom. 2016.09.149.

30. Samira Fikret Cafarova, Akif Shikhan Aliyev, Mahmoud Elrouby, N.Sh. Soltanova, Dilgam Babir Tagiyev. Studying the electrochemical deposition process of molybdenum from aqueous solution of molybdate ions //J. Electrochem. Sci. Eng. 2015. V. 5. No 4. P. 231-235; doi: 10.5599/jese.219.

31. Jafarova S.F., Majidzade V.A., Aliyev A.Sh. Investigation of electroreduction process of thiosulphate ions on the molybdenum electrode // Chemical Problems. 2017. № 1. S. 72-76.

\section{Mo-S NAZIKK YARIMKEÇIRICİ TəBəQӘLӘRININ ELEKTROKIMYYəVİ ÇÖKDÜRÜLMəSİ}

\section{V.A.Məcidzadə, S.F.Cəfərova, A.Ș.Đliyev, N.B.Fərhatova, D.B.Tağıyev}

Sulu məhlullardan Mo-S nazik yarımkeçirici təbəqələrinin birgə elektroçökdürülməsi tədqiq edilmişdir. Potensiodinamik üsulla Pt və Ni elektrodları üzərində tsiklik polyarizasiya əyrilərinin çəkilməsilə molibdenin kükürd ilə birgə çökmə prosesinin potensial sahəsi müəyyən edilmişdir. Həmçinin qalvanostatik üsulla Ni elektrodları üzərində Mo-S nazik təbəqələrinin nümunələri alınmışdır. Alınan bu nümunələrin rentgen-faza analizinin nəticələri göstərir ki, tədqiqatlar nəticəsində $\mathrm{MoS}_{2}$ kimyəvi birləşməsi alınmışdır.

Açar sözlar: $\mathrm{MoS}_{2}$, polyarizasiya, nazik təbəqalar, elektroçökmə, yarımkeçiricilar.

\section{ЭЛЕКТРОХИМИЧЕСКОЕ ОСАЖДЕНИЕ ТОНКИХ ПОЛУПРОВОДНИКОВЫХ ПЛЕНОК Мо-S}

\section{В.А.Меджидзаде, С.Ф.Джафарова, А.Ш.Алиев, Н.Б.Фархатова, Д.Б.Тагиев}

Исследовано совместное электроосаждение тонких полупроводниковых пленок Мо-S из водных электролитов. Снятием циклических поляризационных кривых потенциодинамическим методом на $\mathrm{Pt}$ и $\mathrm{Ni}$ подложках определена область потенциалов совместного электроосаждения молибдена с серой. Гальваностатическим методом на Ni подложках получены образцы совместного электроосаждения молибдена с серой. Рентгенофазовый анализ полученных образцов указал на образование химического соединения $\mathrm{MoS}_{2}$.

Ключевые слова: $\mathrm{MoS}_{2}$, поляризация, тонкие пленки, электроосаждение, полупроводники. 